\title{
Challenges of structural shifts in regional economic systems
}

\author{
Bogdan Dergaliuk ${ }^{1}$ \\ ${ }^{1}$ Candidate of economic sciences, Associate professor of economics and entrepreneurship department, National technical university \\ of Ukraine, "Igor Sikorsky Kiev polytechnic institute"
}

\begin{abstract}
The article highlights the challenges, causes and need for structural modernization of regional economic systems. It is established that the problem of ensuring the balance of structural proportions is not limited to the issues of stimulation positive structural transformations, but also covers the issues of deep theoretical analysis of existing trends in order to identify the prerequisites for global paradigm shifts in the economic system itself. Structural modernization of various levels systems is a worldwide problem of economic systems development. The reasons for the need for structural modernization of the regional economy are highlighted. The problems of Ukraine regional development have been clarified.
\end{abstract}

Keywords: structural modernization of regions, modernization, development, regional economic systems, macroregion, region.

\section{Introduction}

Formulation of the problem. The socio-political processes we see today are characterized by the continuous formation and further expansion of integration ties at all levels of the economic system, aimed at accelerating the development of its subjects. However, in spite of all the benefits of globalization, it is worth paying attention to the strong imbalance of the world economy structure, which threatens the stability of its functioning. That is, gradually the influence of external factors becomes dominant. In doing so, the state loses any tools to ensure that the national economic system is encapsulated from external influences. This, in turn, is facilitated by regional development policies aimed at their structural modernization.

Analysis of recent research and publications. Modernization aspects of the development of economic systems have been studied by such scholars as: G. Alexander, J. Bailey, G. Markowitz, M. Miller, F. Modigliani, M. Friedman, W. Sharp, J. Schumpeter and other researchers.

The relevance of the features of spatial development modernization, the formation of an effective regional modernization policy is widely covered by domestic scientists, among whom are: O. Amosha, B. Burkinsky, M. Butko, S. Vovkanych, A. Vlasyuk, V. Heitz, B. Danylyshyn, M. Dolishny, I. Dunaev, V. Kulishov, P. Lyubchenko, Y. Makogon, M. Mikhalchenko, M. Pashkevich, S. Pyrozhkov, S. Romanyuk, V. Sidenko, V. Symonenko, I. Storonyanska, S. Tulchynska, V. Chuzhikov, S. Stefan, S. Schultz and many others $[2 ; 4 ; 5 ; 6 ; 9]$.

The purpose of this article is to highlight the challenges, causes and need for structural modernization of regional economic systems

\section{The results}

The current state of the global system is characterized by widespread manifestations of antagonistic economic influences, where, on the one hand, access to technology and the dominant system of economic relations create opportunities for dynamic development, and, on the other, destructive tendencies in the sphere of interstate diplomatic interactions together with a global imbalance economies form a number of systemic threats.

Continuous processes of informatization and technologicalisation in the most progressive economies of the world have led to the emergence of a qualitatively new digitized format of both domestic and transnational interactions, which is accompanied by the complication of existing forms and exacerbation of the humanitarian problems of the global level, the discussion of which to resolve and resolve the issues.

In such circumstances, the issues of ensuring national stability, gradual distance and narrowing of the influence of exogenous factors on the flow of internal system processes that rely on structural modernization of the development of the regions of the country become urgent. It should be noted that the problem of ensuring the balance of structural proportions is not limited to the stimulation of positive structural transformations, but also covers the issues of deep theoretical analysis of existing trends in order to identify the prerequisites for global paradigm shifts in the most economic system, which would allow effective forecasting and minimization threatening trends on the cast. 
The modern paradigm of the countries`development in accordance with the requirements of the new regionalism puts regional development at the forefront [8, p. 27]. The regional development of the country determines the proportionality and balance of the economic development of the country as a whole. At the same time, regional differentiation has been increasing recently, including in Ukraine.

The dialectics of the current state Ukrainian economy is marked by the formation of civilizational-scale threats described earlier, which are prerequisites for deepening existing structural problems, while creating potential opportunities and promising directions of their solution. Moreover, the European integration course chosen by Ukraine requires qualitatively new approaches in the formation of key principles and directions of structural modernization of Ukrainian regions.

Structural modernization of systems of various levels is a worldwide problem of economic systems development. Scientists determine the relevance and ways of finding structural changes in the economy at different levels.

The reasons for the structural modernization of the regional economy include the following:

* change of values in the system of consumer needs under the influence of mass social phenomena or achievements of scientific and technological progress;

* qualitative changes in the material and technical base of production under the influence of innovation processes intensification;

* influence of market self-regulation processes;

* the impact of existing structural shifts or structural shifts that have occurred in the past;

* cyclical processes of the economic system (from small-scale economic fluctuations to global economic crises);

* informatization and digitization of the global economic space;

* global tendencies towards liberalization of foreign economic relations between the states, etc.

The modernization of the regional economy with its inherent principles, approaches and instruments is carried out at the expense of the structural policy of the state, but each region, taking into account the available resources and potential, builds its own direction and determines the accents regarding the use of the structural modernization tools of the region, its directions and goals. At the same time, the structural modernization of the regional economy is a component of the modernization of the country's economy.

The problems of regional development in Ukraine include:

\# unevenness and deepening of the economic development asymmetry, which leads to deeper differentiation in the social development of regions;

\# insufficient coherence and activity of state and regional policy on regional development and their main aspects;

\# increase due to geopolitical circumstances, dependence of production structures on the import of resources and fluctuations in prices for them;

* low adaptability of the regional economy to rapid changes in the global environment;

* low competitiveness of regional systems in the world market;

* slow technological updating and backwardness of innovative processes of development of regional economies;

\# non-diversified structure of production of regions;

* orientation of production of many regions in the heavy industry, including the processing of primary raw materials and their extraction;

\& downward trend of production and its low efficiency and so on.

Contemporary regional policy should be based on strategic priority areas of reform and modernization of the regional economy, aiming at sustainable regional development, which at the same time includes the development of social, economic and environmental spheres of the regions. Structural regional policy is usually concerned with economic policy, but it also affects social, environmental, and cultural development, which is directly related to economic shifts and the dynamics of economic growth.

\section{Conclusions}

Thus, the conducted study of structural modernization of regions makes it possible to point out that the main purpose of its implementation are the reasons for the deepening of the asymmetric economic development of the regions of Ukraine and the need for qualitative shifts in regional economic systems. Structural modernization of regions depends on the potential and resources of the regions. Modernization shifts require changes in the management of economic processes, which can give impetus to change and increase their effectiveness. 


\section{References}

[1] Krush, P.V. ta in. (2014), Determinanty rozvytku natsional'noho hospodarstva [Determinants of the development of the national economy], NTUU “KPI", Kyiv, Ukraine.

[2] Dunaiev, I.V. (2015), "Modernization of regional economic policy: identification and semantic analysis of the conceptual apparatus", Aktual'ni problemy derzhavnoho upravlinnia. Odesa, Vyd-vo ORI NADU, vol. 4, no. 64, pp. 16-20.

[3] Mylen'kyj, V.M. (2013), "Theoretical approaches to the modernization of the regional economy", Teoretychni i praktychni aspekty ekonomiky ta intelektual'noi vlasnosti, vol. 1, no. 2, pp. 322-326.

[4] Mykhal'chenko, M. (2005), Politychna real'nist' v Ukraini: transformatsiia, modernizatsiia, revoliutsiia? [Political reality in Ukraine: transformation, modernization, revolution?], Suchasna ukrains'ka polityka. Polityky i politolohy pro nei, Kyiv, Ukraine.

[5] Pashkevych, M.S. and Lysunets', K.P. (2014), "Principles of modernization of economy of regions of Ukraine in the aspect of modern regional policy”, Efektyvna ekonomika, vol. 10, available at: http://nbuv.gov.ua/UJRN/efek_2014_10_7 (Accessed 23 January 2019).

[6] Tul'chyns'ka, S.O. (2009), Intelektual'no-innovatsijna modernizatsiia ekonomiky Ukrainy: teoretyko-metodolohichni aspekty [Intellectual-innovative modernization of the Ukrainian economy: theoretical and methodological aspects], NTUU «KPI», Kyiv, Ukraine.

[7] Tul'chyns'ka, S.O. (2014), Determinanty stanovlennia novoho rehionalizmu: teoriia, metodolohiia, praktyka [Determinants of the emergence of a new regionalism: theory, methodology, practice], Vyd-vo «PP Vyshemyrs'kyj V.S.», Kherson, Ukraine.

[8] Tul'chyns'kyj, R.V. (2018), Determinanty stanovlennia novoho rehionalizmu: teoriia, metodolohiia, praktyka [Determinants of the emergence of a new regionalism: theory, methodology, practice], Vyd-vo «PP Vyshemyrs'kyj V.S.», Kherson, Ukraine.

[9] Shtefan, S.I. and Korotieieva, H.S. (2014), "Financial Institutions and Instruments of Modernization of the Economy of the Regions of Ukraine", Komunal'ne hospodarstvo mist, vol. 113, pp. 223-228. 